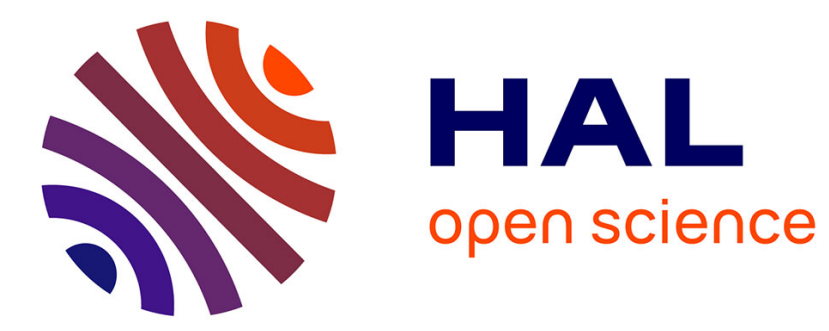

\title{
Biohydrogen production from Food Waste: Current Status, Limitations, and Future Perspectives
}

Yeo-Myeong Yun, Mo-Kwon Lee, Seong-Won Im, Antonella Marone, Eric

Trably, Sang-Ryong Shin, Min-Gyun Kim, Si-Kyung Cho, Dong-Hoon Kim

\section{- To cite this version:}

Yeo-Myeong Yun, Mo-Kwon Lee, Seong-Won Im, Antonella Marone, Eric Trably, et al.. Biohydrogen production from Food Waste: Current Status, Limitations, and Future Perspectives. Bioresource Technology, 2018, 248, pp.79-87. 10.1016/j.biortech.2017.06.107 . hal-02628592

\section{HAL Id: hal-02628592 \\ https://hal.inrae.fr/hal-02628592}

Submitted on 26 May 2020

HAL is a multi-disciplinary open access archive for the deposit and dissemination of scientific research documents, whether they are published or not. The documents may come from teaching and research institutions in France or abroad, or from public or private research centers.
L'archive ouverte pluridisciplinaire HAL, est destinée au dépôt et à la diffusion de documents scientifiques de niveau recherche, publiés ou non, émanant des établissements d'enseignement et de recherche français ou étrangers, des laboratoires publics ou privés. 


\section{Accepted Manuscript}

Review

Biohydrogen production from Food Waste: Current Status, Limitations, and Future Perspectives

Yeo-Myeong Yun, Mo-Kwon Lee, Seong-Won Im, Antonella Marone, Eric Trably, Sang-Ryong Shin, Min-Gyun Kim, Si-Kyung Cho, Dong-Hoon Kim

PII: S0960-8524(17)31011-8

DOI: http://dx.doi.org/10.1016/j.biortech.2017.06.107

Reference: BITE 18344

To appear in: Bioresource Technology

Received Date: $\quad 30$ April 2017

Revised Date: $\quad 19$ June 2017

Accepted Date: $\quad$ 20 June 2017

Please cite this article as: Yun, Y-M., Lee, M-K., Im, S-W., Marone, A., Trably, E., Shin, S-R., Kim, M-G., Cho, S-K., Kim, D-H., Biohydrogen production from Food Waste: Current Status, Limitations, and Future Perspectives, Bioresource Technology (2017), doi: http://dx.doi.org/10.1016/j.biortech.2017.06.107

This is a PDF file of an unedited manuscript that has been accepted for publication. As a service to our customers we are providing this early version of the manuscript. The manuscript will undergo copyediting, typesetting, and review of the resulting proof before it is published in its final form. Please note that during the production process errors may be discovered which could affect the content, and all legal disclaimers that apply to the journal pertain. 


\section{Biohydrogen production from Food Waste: Current Status, Limitations, and}

\section{Future Perspectives}

Yeo-Myeong Yun ${ }^{\mathrm{a}}$, Mo-Kwon Lee ${ }^{\mathrm{b}}$, Seong-Won $\mathrm{Im}^{\mathrm{b}}$, Antonella Marone ${ }^{\mathrm{c}}$, Eric Trably ${ }^{\mathrm{c}}$, SangRyong Shin ${ }^{\mathrm{b}}$, Min-Gyun Kim ${ }^{\mathrm{b}}, \mathrm{Si}-\mathrm{Kyung}$ Cho ${ }^{\mathrm{d}}$, Dong-Hoon Kim,*

${ }^{\text {a} D e p a r t m e n t ~ o f ~ C i v i l ~ a n d ~ E n v i r o n m e n t a l ~ E n g i n e e r i n g, ~ K A I S T, ~ 373-1 ~ G u s e o n g-d o n g, ~ Y u s e o n g-~}$ gu, Daejeon 305-701, Republic of Korea

${ }^{\mathrm{b}}$ Department of Civil Engineering, Inha University, 100 Inharo, Nam-gu, Incheon 402-751, Republic of Korea

'INRA, UR0050 Laboratoire de Biotechnologie de l'Environnement, F-11100 Narbonne, France ${ }^{\mathrm{d}}$ Department of Biological and Environmental Science, Dongguk University, 32 Dongguk-ro, Ilsandong-gu, Goyang, Gyeonggi-do, Republic of Korea *Corresponding author: Dong-Hoon Kim (E-mail address: dhkim77@inha.ac.kr, Tel: +82-32860-7562; fax: +82-32-873-7560)

\section{ABSTRACT}

Among the various biological routes for $\mathrm{H}_{2}$ production, dark fermentation is considered the most practically applicable owing to its capability to degrade organic wastes and high $\mathrm{H}_{2}$ production rate. Food waste (FW) has high carbohydrate content and easily hydrolysable in nature, exhibiting higher $\mathrm{H}_{2}$ production potential than that of other organic wastes. In this review article, first, the current status of $\mathrm{H}_{2}$ production from $\mathrm{FW}$ by dark fermentation and the strategies 
applied for enhanced performance are briefly summarized. Then, the technical and economic limitations of dark fermentation of FW are thoroughly discussed. Economic assessment revealed that the economic feasibility of $\mathrm{H}_{2}$ production from $\mathrm{FW}$ by dark fermentation is questionable. Current efforts to further increase $\mathrm{H}_{2}$ yield and waste removal efficiency are also introduced. Finally, future perspectives along with possible routes converting dark fermentation effluent to valuable fuels and chemicals are discussed.

Keywords: Food waste; Dark fermentation; Hydrogen; Economic assessment; Integrated system

\section{INTRODUCTION}

Food waste $(\mathrm{FW})$ is one of the most abundant and problematic organic solid wastes, accounting for 15-63\% of total municipal solid wastes worldwide (AIT, 2010; Jang et al., 2015). Unless properly managed, it releases odor and leachate during collection and transportation due to its high volatile solids (VS: $85-95 \%$ ) and moisture content (75-85\%). However, as FW has high energy content, the generation of fuels and chemicals while reducing waste seems ideal (Breunig et al., 2017). In particular, it could be more valuable if clean fuel (also it could be a raw material for chemical processing), hydrogen $\left(\mathrm{H}_{2}\right)$, is recovered during the treatment process.

Currently, $\mathrm{H}_{2}$ is almost exclusively made by physico-chemical methods that split fossil fuels. However, it is an environmental contradiction that a clean fuel is generated from polluting and limited sources under high temperature pressure condition, emitting significant greenhouse gases (Ewan and Allen, 2005). Therefore, it is important to use other sources and methods to obtain $\mathrm{H}_{2}$ in a renewable, sustainable, and environmentally friendly way. Biological $\mathrm{H}_{2}$ production processes are more environmentally friendly and less energy consumptive than physico-chemical 
ones. They include a wide range of approaches to generate $\mathrm{H}_{2}$, including direct biophotolysis, indirect biophotolysis, photo-fermentation, and dark fermentation (Kim and Kim, 2011). Among them, dark fermentation is considered the most practically applicable method since it does not require external energy, and its $\mathrm{H}_{2}$ production rate is much faster than other processes. In addition, when combined with the treatment of waste such as FW, it can solve two problems simultaneously: the reduction of environmental burden and production of clean energy.

Since FW has higher carbohydrate content and biodegradability than other organic wastes, high $\mathrm{H}_{2}$ production potential and rate are generally achievable. Dark fermentation performance has been maximized through various pretreatment techniques, the optimization of operation parameters, and the employment of various reactor types. However, from engineering and economical point of views, there are still doubts as to whether this process is ready to be practically applied. In this review article, first, the current status of $\mathrm{H}_{2}$ production from $\mathrm{FW}$ by dark fermentation and the strategies applied for enhanced performance are briefly summarized. Then, the technical limitation of low $\mathrm{H}_{2}$ yield from $\mathrm{FW}$ by dark fermentation is mentioned, and the economic feasibility is discussed. Finally, current efforts to further increase $\mathrm{H}_{2}$ yield and waste removal efficiency along with future perspectives on dark fermentation of FW are covered.

\section{CURRENT STATUS}

\subsection{Batch operation}

$\mathrm{H}_{2}$ production performances under batch operation and the strategies applied are arranged in Table 1. The main purpose of batch studies was to increase $\mathrm{H}_{2}$ yield, which have been expressed in three units: $\mathrm{mol} \mathrm{H}_{2} / \mathrm{mol}$ hexose, $\mathrm{mL} \mathrm{H}_{2} / \mathrm{g}$ volatile solids (VS), and $\mathrm{mL} \mathrm{H}_{2} / \mathrm{g}$ chemical oxygen demand (COD). Since the $\mathrm{H}_{2}$ production potential of carbohydrates is much higher than lipids 
and proteins, the $\mathrm{H}_{2}$ yield on a hexose basis is an important factor in the evaluation of the performance from a scientific point of view (Dong et al., 2009). Under anaerobic condition, carbohydrate degradation proceeds through several metabolic pathways, as shown in Table 2. Some liquid metabolites such as acetate and butyrate are related with $\mathrm{H}_{2}$ production, but others are not. Theoretically, the maximum $\mathrm{H}_{2}$ yield from hexose is $4 \mathrm{~mol} \mathrm{H}_{2} / \mathrm{mol}$ hexose, if all carbohydrates are degraded into acetate. However, acetate cannot be the only metabolite due to thermodynamic reason. The $\mathrm{H}_{2}$ yield, in general, does not exceed $3 \mathrm{~mol} \mathrm{H}_{2} / \mathrm{mol}$ hexose (Lalman et al., 2013).

The expression of $\mathrm{H}_{2}$ yield on a hexose basis is not sufficient to determine whether a feedstock is suitable for $\mathrm{H}_{2}$ production. The $\mathrm{H}_{2}$ yields on VS and COD basis are more directly related with $\mathrm{H}_{2}$ production potential of organic solid wastes. Similar $\mathrm{H}_{2}$ yields could be obtained from FW, sewage sludge, and livestock waste on a hexose basis, but FW is considered a much more feasible feedstock for $\mathrm{H}_{2}$ production, owing to its higher carbohydrate content. The carbohydrate content of FW ranges 30-70\%, while those of sewage sludge and livestock waste are lower than than $10 \%$ (Kim et al., $2011^{\mathrm{b}}$ ). Considering that $1 \mathrm{~kg} \mathrm{COD}$ is equivalent to $1.4 \mathrm{~m}^{3} \mathrm{H}_{2}$, the $\mathrm{H}_{2}$ yield of $133 \mathrm{~mL} \mathrm{H}_{2} / \mathrm{g} \mathrm{COD}_{\text {added }}$ achieved by Jang et al. (2015) corresponds to the conversion of almost $10 \%$ of the energy content of $\mathrm{FW}$ into $\mathrm{H}_{2}$. Authors may choose the unit of $\mathrm{H}_{2}$ yield on the purpose of their study and results, but it is highly recommended that substrate characteristics including carbohydrate content, total COD, and VS concentrations be presented.

Various pretreatments such as heat-, alkali-, and acid-treatments have been applied to FW, and have increased the $\mathrm{H}_{2}$ yield by 5-20 times compared to the control (Im et al., 2012; Kim et al., 2009; Kim et al., 2014, Jang et al., 2015). It seemed that the role of pretreatment was not to increase the hydrolysis but to select microbes favorable for $\mathrm{H}_{2}$ production. In the previous 
studies shown in Table 1, there were no differences in the solubilization (soluble COD/total COD) of untreated and pretreated FW after fermentation. Microbial analysis conducted by next generation sequencing clearly showed that lactic acid bacteria (LAB) were the most abundant species in untreated FW while $\mathrm{H}_{2}$-producers were dominant in the pretreated one (Kim et al., 2014; Jang et al., 2015). Owing to their unique metabolic characteristics and antibiotic function, LAB are enriched in many fermentation processes of milk, meats, cereals, and yegetables, and their all known metabolic reactions degrading carbohydrates are irrelevant to $\mathrm{H}_{2}$ production (Stiles and Holzapfel, 1997). LAB are also known to produce bacteriocins, which suppress the activity of $\mathrm{H}_{2}$-producers (Noike et al., 2002). The strength of pretreatment was also found to be important for increasing $\mathrm{H}_{2}$ production. As the heating temperature increased from $60^{\circ} \mathrm{C}$ to $90^{\circ} \mathrm{C}$, a $\mathrm{H}_{2}$ yield gradually increased (Kim et al., 2009). Acid pretreatment at $\mathrm{pH} 4$ did not show any improved effect on $\mathrm{H}_{2}$ production (Kim et al., 2014), and the amount of $\mathrm{H}_{2}$ production from alkali-treated FW at pH 13 was half of the amount achieved at pH 11 and 12 (Jang et al., 2015).

The effects of operating parameters including $\mathrm{pH}$, substrate concentration, temperature, and F/M (food to microorganism ratio) on batch $\mathrm{H}_{2}$ production from $\mathrm{FW}$ have been studied. According to Kim et al. $\left(2011^{\mathrm{a}}\right)$ and Xiao et al. (2013), the optimal initial pH was found to be 8.0. Although the period for $\mathrm{pH}$ drop from the initial values of 5.0-9.0 to 5.0 was less than one-tenth of the entire fermentation, this short period significantly affected the $\mathrm{H}_{2}$ production performance. The $\mathrm{H}_{2}$ yield ranged 1.6-1.7 $\mathrm{mol} \mathrm{H}_{2} / \mathrm{mol}$ hexose $\mathrm{added}_{\text {at }}$ 5-60 g COD/L (on a carbohydrate basis), but decreased to $1.39 \mathrm{~mol} \mathrm{H}_{2} / \mathrm{mol}$ hexose $e_{\text {added }}$ at $80 \mathrm{~g} \mathrm{COD} / \mathrm{L}$, indicating substrate inhibition (Kim et al., 2014). Compared to mesophilic condition, thermophilic condition showed higher $\mathrm{H}_{2}$ yield, which was attributed to the fact that the activity of indigenous LAB was suppressed at high temperature condition (Kim et al., 2011 ${ }^{\mathrm{c}}$ ). A high F/M ratio (on a VS basis) ranging 7-10 was 
preferable for $\mathrm{H}_{2}$ production, while the highest yield of $57 \mathrm{~mL} \mathrm{H}_{2} / \mathrm{g} \mathrm{VS}$ added was attained at an F/M ratio of 7 (Pan et al., 2008).

Even though FW is a suitable substrate for producing $\mathrm{H}_{2}$ owing to its high carbohydrate content and easily hydrolysable nature, it may be short of nitrogen which is a vital nutrient for the growth of $\mathrm{H}_{2}$-producers. Sewage sludge is a good candidate as a co-substrate to meet the nitrogen source requirement. Kim et al. (2004) and Sreela-or et al. (2011) found that the addition of sludge to FW led to a more balanced carbon to nitrogen ratio, increasing $\mathrm{H}_{2}$ production. Unlike previous studies, the increased performance by sewage sludge addition was ascribed to the existence of $\mathrm{Fe}$ and $\mathrm{Ca}$ at much higher concentrations in the sewage sludge compared to those in the FW (Kim et al., 2011 ${ }^{\mathrm{b}}$ ). Zhou et al. (2013) achieved a high $\mathrm{H}_{2}$ yield from FW by adding primary sludge and waste activated sludge separately.

\subsection{Continuous operation}

The main goal of a continuous process in organic waste treatment is to retain an active microbial consortium at a high concentration for stable and fast treatment. Therefore, instead of $\mathrm{H}_{2}$ yield, volumetric $\mathrm{H}_{2}$ production rate (VHPR) is often considered the main important indicator to tell the performance of continuous operation. To achieve high VHPR, the input of a large amount of FW, often expressed as high organic loading rate (OLR), has been attempted by controlling the substrate concentration and hydraulic retention time (HRT). As shown in Table 3, the highest VHPR achieved from FW was $10.7 \mathrm{~L} \mathrm{H}_{2} / \mathrm{L} / \mathrm{d}$, which was far lower than the value obtained from liquid-type organics. Wu et al. (2006) designed a reactor containing siliconeimmobilized and self-flocculated sludge, and obtained the documented highest $\mathrm{H}_{2}$ production rate of $15 \mathrm{~L} \mathrm{H}_{2} / \mathrm{L} / \mathrm{h}$ from sucrose containing wastewater. This huge difference resulted from the 
low reaction rate of the hydrolysis step involved in solid waste degradation.

A continuous stirred tank reactor (CSTR) was the most frequently used reactor type for the continuous operation, but other reactor configurations such as anaerobic baffled reactor, membrane bioreactor, and sequencing batch reactor, whose purpose were to separate solid retention from hydraulic retention, have been employed. Kim et al. (2008) controlled solid retention time (SRT) and HRT separately at the same OLR, and achieved the highest VHPR of 2.73 $\mathrm{L} \mathrm{H}_{2} / \mathrm{L} / \mathrm{d}$ at SRT $120 \mathrm{~h}$ and HRT $36 \mathrm{~h}$. A high SRT can be attained by providing enough settling time, but there could be a limitation due to the rise of biogas and lipid in the acidified broth during settling time (Kim et al., 2010). It seemed that membrane bioreactors were successful to achieve high VHPR (Lee et al., 2014). However, these configurations may face technical difficulties, such as fouling, in long-term operation.

It was difficult to draw general conclusion on the effect of HRT and substrate concentration on continuous $\mathrm{H}_{2}$ production from FW. For example, at a fixed HRT of $1.6 \mathrm{~d}$, the highest VHPR was observed at the lowest substrate concentration of $46.4 \mathrm{~g} \mathrm{COD} / \mathrm{L}$ in an anaerobic baffled reactor, while the highest VHPR was observed at the highest substrate concentration of $112 \mathrm{~g} \mathrm{COD/L}$ at a fixed HRT of $4 \mathrm{~d}$ in an intermittent CSTR (Lee et al., 2010 ${ }^{\mathrm{b}}$ ). We cannot tell which is right or wrong, but it is reasonable to conclude that the optimal conditions vary depending on the feedstock used, inoculum, and other operating parameters, such as temperature and $\mathrm{pH}$. Compared to the batch studies, thermophilic regime was more frequently used than mesophilic regime in continuous studies. According to Shin et al. (2004), thermophilic operation showed a $\mathrm{H}_{2}$ yield of $1.8 \mathrm{~mol} \mathrm{H}_{2} / \mathrm{mol} \mathrm{hexose}_{\text {added }}$, while it was limited to $0.1 \mathrm{~mol} \mathrm{H}_{2} / \mathrm{mol} \mathrm{hexose}_{\text {added }}$ under mesophilic operation. This might be related to the vigorous activity of the indigenous LAB in the mesophilic temperature range. To inhibit the LAB activity, Kim et al. (2008) and Kim et al. 
(2010) fed FW fed after alkali-pretreatment at pH 12 under mesophilic operation. Co-digestion with brown water, which acted as diluting water to decrease substrate concentration of FW, has been attempted (Paudel et al., 2017).

\section{LIMITATIONS}

\subsection{Low $\mathrm{H}_{2}$ yield}

As mentioned '2.1 Batch operation', 4 moles of $\mathrm{H}_{2}$ can be generated from 1 mole of glucose in dark fermentation. However, the actual $\mathrm{H}_{2}$ yield is lower than $50 \%$ of the theoretical maximum, and this is attributed to the (1) thermodynamic limitation, (2) existence of non- $\mathrm{H}_{2}$ producers in the broth, and (3) acetogenic $\mathrm{H}_{2}$-consuming reaction. These reasons can be applied to all types of feedstock used in dark fermentation, and were well explained by Lalman et al. (2013).

FW consists of not only carbohydrates but also other nutrients such as proteins and lipids. Numerous studies have shown that carbohydrates are preferred for $\mathrm{H}_{2}$ production in dark fermentation. $\mathrm{H}_{2}$ yields of $19.3-96.0 \mathrm{~mL} / \mathrm{g}$ VS have been achieved from cabbage, carrots, and rice, while those from the protein-(egg and lean meat) and lipid-(fat and chicken skin) rich FW were negligible (Dong et al., 2009; Okamoto et al., 2000). Experimental results indicated that the $\mathrm{H}_{2}$ production potential of carbohydrate-rich solid waste was approximately 20 times higher than that of fat-and protein-rich ones (Lay et al., 2003). Glycerol, the main component of lipids, could be a source of $\mathrm{H}_{2}$ production but small amount. Heyndrickx et al. (1991) reported that glycerol is not a suitable substrate for $\mathrm{H}_{2}$ production, but is an excellent substrate for solvent production. Proteins are hydrolyzed to various amino acids, and there are two types of anaerobic amino acid degradation reactions by Clostridium sp.: sole amino acid degradation and the Stickland reaction.

A small amount of $\mathrm{H}_{2}$ can be generated via sole amino acid degradation, but it would be 
consumed in the Stickland reaction. The carbohydrate content of FW depends on the diet and storage condition (time and temperature), and ranges from 30\% to $70 \%$ on a COD basis (Li et al., 2008). Achieving a $\mathrm{H}_{2}$ yield of $2 \mathrm{~mol} \mathrm{H}_{2} / \mathrm{mol}$ hexose is generally considered as a success, but this corresponds to only $5 \%$ of the energy content of FW with a carbohydrate content of $30 \%$.

The other problem associated with obtaining low $\mathrm{H}_{2}$ yield from $\mathrm{FW}$ is the continued supply of indigenous non- $\mathrm{H}_{2}$ producers, in particular, $\mathrm{LAB}$. When $\mathrm{FW}$ was cultivated at $35^{\circ} \mathrm{C}$ without any pretreatment and addition of inoculum, it was decomposed mainly to lactate (Kim et al., 2009). Jo et al. (2007) observed unstable $\mathrm{H}_{2}$ fermentation performance in the treatment of $\mathrm{FW}$ under continuous operation, and attributed this to the supply of indigenous LAB. By applying various pretreatments such as heat-, alkali-, and acid-shock, indigenous LAB were selectively killed while spore-forming bacteria including Clostridium sp. were cultivated (Kim et al., 2009). Also, it was reported that alkali-pretreatment of $\mathrm{FW}$ at $\mathrm{pH} 12.5$ for $1 \mathrm{~d}$ was an essential step for the stable $\mathrm{H}_{2}$ production (Kim et al., 2008). Even though $\mathrm{FW}$ was pretreated at $\mathrm{pH} 11$ or 12, stable $\mathrm{H}_{2}$ production was not sustained with the reactivation of LAB (Jang et al., 2015; Kim et al., 2009). To recover the performance, alkali-treatment of the entire broth in the fermenter has been attempted, which increased the $\mathrm{H}_{2}$ yield from 0.4 to $0.8 \mathrm{~mol} \mathrm{H}_{2} / \mathrm{mol}_{\text {hexose }}$ added (Kim et al., 2010). However, this method imposes a high economic burden and cannot warrant stable production since it frequently requires this kind of chemical-shock.

\subsection{Economic feasibility}

Although $\mathrm{H}_{2}$ would be derived from waste materials via an environmentally friendly route, there is still a concern as to whether dark fermentation of FW is economically feasible or not. To address this issue, we conducted an economic assessment, assuming a high $\mathrm{H}_{2}$ yield of $2.26 \mathrm{~mol}$ 
$\mathrm{H}_{2} / \mathrm{mol}$ hexose at an OLR of $100 \mathrm{~kg} \mathrm{COD} / \mathrm{m}^{3} / \mathrm{d}$ (obtained from the highest values in Tables 1 and 3), and a lifespan of 20 years while operating $360 \mathrm{~d}$ per year. The COD concentration of FW and carbohydrate content were assumed to be $200 \mathrm{~kg} / \mathrm{m}^{3}$ and $50 \%$ on a COD basis, respectively. The fermenter size was set to $200 \mathrm{~m}^{3}$, treating 100 tons of FW per day.

Table 4 summarizes the costs and benefits for the economic assessment, including the capital, annual operating cost, and profits. The capital cost includes the construction costs of all facilities, land use, and installation costs. The construction cost was estimated according to the study of Vrije and Claassen. (2013), and the cost of land use and set up was estimated to be 50\% of the total construction cost (Van Haandel and Lettinga, 1994). Operating costs consisted of maintenance costs such as those for electricity, water use, and annual expenses like labor, and the use of chemicals. Annual expenses and maintenance costs were estimated to be $25 \%$ of the capital cost (Benemann, 1998), and the labor cost was estimated to be $50 \%$ of the total operating cost (Luccio et al., 2002). The profit can be gained from the treatment of FW, which is 100 USD/ton waste (NABO, 2012). However, since COD removal is limited to $10 \%$ in dark fermentation, the profit was calculated using a rate of $10 \mathrm{USD} /$ ton FW. The cost for purification cost, removing $\mathrm{CO}_{2}$ from the produced biogas, was calculated that is carried out through pressure swing adsorption (PSA).

Based on the estimated costs above, the total capital cost and annual operating costs are 1,636,560 USD and 548,568 USD/y, respectively. Meanwhile, 360,000 USD of profit could be gained through the treatment of FW. Considering the amount of 949,200 $\mathrm{m}^{3} \mathrm{H}_{2}$ (10 ton Carbo. $\mathrm{COD} / \mathrm{d} \times 2.26 / 12 \times 1,400 \mathrm{~m}^{3} \times 360 \mathrm{~d}$ ) production per year, the $\mathrm{H}_{2}$ production cost is estimated to be $3.2 \mathrm{USD} / \mathrm{kg} \mathrm{H} \mathrm{H}_{2}(=[(1,636,560 / 20+548,568)-360,000] /(949,200 / 11.2))$. This is lower than the previously cost ranging 10-30 USD/kg H (Han et al., 2016 ; Han et al., 2016 ; Li et al., 
2012), which might resulted from the high performance $\left(\mathrm{H}_{2}\right.$ yield and OLR) values applied in this economic assessment. However, this production cost is still higher than the current selling price of $\mathrm{H}_{2}\left(0.5-3.2 \mathrm{USD} / \mathrm{kg} \mathrm{H}_{2}\right.$ ) (Bartels et al., 2010), indicating that the economic feasibility of $\mathrm{H}_{2}$ production from $\mathrm{FW}$ by dark fermentation is questionable.

\section{STRATEGIES TO INCREASE $\mathrm{H}_{2}$ YIELD AND OBTAIN MORE ENERGY}

\subsection{Microbial electrolysis cells}

Increasing the $\mathrm{H}_{2}$ yield from dark fermentation remains one of the main challenges for largescale $\mathrm{H}_{2}$ production. Dark fermentation only results from partial oxidation of organic substrates, and more than two thirds of the carbon and $\mathrm{H}_{2}$ contents is converted to microbial metabolic byproducts. Among the biotechnologies that could utilize the metabolic byproducts generated by dark fermentation processes, microbial electrolysis cells (MECs), an emerging technology related to microbial fuel cells (MFC), is a very promising candidate for the augmentation of classical, single-stage dark fermentation to generate $\mathrm{H}_{2}$ with high efficiency (Kumar et al., 2016).

In MEC applications, however, food-processing wastewater rather than FW were more often used. During dark fermentation of FW, 30-60\% of VS reduction is generally achieved, but the remained VS concentration (5-50 g/L depending on the dilution rate) is still high to directly apply to MECs. A wide variety of wastes and wastewaters from the food industry has been investigated for electricity generation using MFCs (ElMekawy et al., 2015), but, to date, only few studies dealt with $\mathrm{H}_{2}$ production by MECs both as a single-stage process or coupled with dark fermentation in a two-stage system (Dhar et al., 2015; Lu et al., 2009; Marone et al., 2017; Moreno et al., 2015). 
By combining an MECs with a fermentation system for treating molasses wastewaters, an overall $\mathrm{H}_{2}$ recovery of $96 \%$ has been obtained. The corresponding electrical energy efficiency, based on voltage input, reached up to $287 \%$, and the overall energy efficiency (relative to the electrical input and substrate) reached 70\% (Lu et al., 2009). Similarly, the overall energy recovery achieved from sugar beet juice using an integrated biohydrogen process of dark fermentation and MEC was $57 \%\left(6 \mathrm{~mol} \mathrm{H}_{2} / \mathrm{mol} \mathrm{hexose}_{\text {added }}\right)$, while the individual efficiencies of energy recovery in dark fermentation and MECs were only 35\% and 34\%, respectively (Dhar et al., 2015). Recently, Marone et al. (2017) evaluated and compared six different industrial wastewaters and by-products coming from cheese, fruit juice, paper, sugar, fruit processing and spirits factories for their potential to generate $\mathrm{H}_{2}$ by coupling dark fermentation with an MEC in a two-step process. Regardless of the substrate, the amount of energy produced was at least three times higher than the amount of supplied energy, where the electrical energy efficiency ranged from 336 to $725 \%$. The $\mathrm{H}_{2}$ yield increased by up to 13 times when both processes were used in comparison to dark fermentation alone. Among the tested wastewaters, fruit juice wastewater was the most suitable substrate since it provided the best total hydrogen yield of $1.6 \pm 0.3 \mathrm{~L} \mathrm{H}_{2} / \mathrm{g}$ $\mathrm{COD}_{\text {consumed }}$ (corresponding to around $9.82 \mathrm{~mol} \mathrm{H}_{2} / \mathrm{mol}$ hexose) with $72 \%$ of COD removal, without the need of dilution. Meanwhile, taking into account the need of dilution, the most interesting substrates to be exploited for $\mathrm{H}_{2}$ production in such a two-stage system were vinasse residues generated from spirit production followed by cheese whey. Indeed, up to $28 \pm 5 \mathrm{~L}_{\text {of }} \mathrm{H}_{2}$ could be produced per liter of raw vinasse and $8.1 \pm 1.4 \mathrm{~L}$ of $\mathrm{H}_{2}$ could be produced per liter of raw cheese whey (Marone et al., 2017).

One of the main current challenges for MECs is scaling up. In this domain, further research is required, since most of the studies carried out until now, which succeeded in $\mathrm{H}_{2}$ production, dealt 
with bench-scale reactors that provided useful information about the functioning of MEC technology but do not allow any prediction on its success at industrial scale. Indeed, up to now, only Cusick et al. (2011) have attempted to scale-up MECs from bench experiments to a significant pilot-scale system for $\mathrm{H}_{2}$ production from food industry residues. The authors developed an MEC system to treat winery wastewaters with a maximum capacity of $1 \mathrm{~m}^{3}$. Although a consistent continuous soluble COD removal of $62 \pm 20 \%$ was achieved, most of the produced biogas was $\mathrm{CH}_{4}$, comprising $86 \pm 6 \%$ of the biogas, and no $\mathrm{H}_{2}$ was recovered. $\mathrm{CH}_{4}$ contamination has often been reported as the main cause of process failure in MEC treating complex substrates (Lalaurette et al., 2009). When treating FW or food-processing wastewater and by-products by MEC, excluding the use of chemical inhibitors (Marone et al., 2017; Montpart et al., 2014; Rago et al., 2017) which is not applicable at industrial scale, several strategies have been proposed to prevent $\mathrm{CH}_{4}$ evolution. These include (i) the use of low operational temperature (i.e. $9^{\circ} \mathrm{C}$ ) (Wang et al., 2014), (ii) a low acetate concentration and hydraulic retention time (Sosa-hernández et al., 2016), (iii) air exposure of the cathode and reduction of the time for a fed-batch cycle ( $\mathrm{Lu}$ et al., 2009), and (iv) the use of a particular substrate (Montpart et al., 2014; Rago et al., 2017).

\section{2. $\mathrm{CH}_{4}$ production}

As shown in Table 5, another approach for both increasing bioenergy recovery and enhancing pollutant (often referred to as COD) removal is to further utilize remaining organic acids by methanogens to produce $\mathrm{CH}_{4}$. The fundamental difference between the conventional two-stage process and the two-stage process with $\mathrm{H}_{2}$ and $\mathrm{CH}_{4}$ co-production is that the latter has a specific environment favorable for $\mathrm{H}_{2}$ production while the former does not. Co-combustion of $\mathrm{H}_{2}$ and 
$\mathrm{CH}_{4}$ mixture (often referred to as 'hythane') could reduce less nitrogen oxides emissions compared to the combustion of $\mathrm{CH}_{4}$ alone (Cooney et al., 2007).

Han and Shin (2004) found that the cogeneration of $\mathrm{H}_{2}$ and $\mathrm{CH}_{4}$ from $\mathrm{FW}$ markedly increased the bioenergy conversion efficiency from $8 \%$ in only $\mathrm{H}_{2}$ production to $78 \%$. Antonopoulou et al (2008) also operated the two-stage fermentation system and maximum $\mathrm{H}_{2}$ and $\mathrm{CH}_{4}$ yields were found to be $41 \mathrm{~mL} \mathrm{H}_{2} / \mathrm{g} \mathrm{COD}$ and $310 \mathrm{~mL} \mathrm{CH}_{4} / \mathrm{g} \mathrm{COD}$, equivalent to $71 \%\left[\mathrm{H}_{2}(3 \%)+\mathrm{CH}_{4}\right.$ $(68 \%)$ ] of energy content in the FW with $94 \%$ of COD removal efficiency. The $\mathrm{H}_{2}$ and $\mathrm{CH}_{4}$ yield in the pilot-scale of two-stage fermentation system were $290 \mathrm{~mL} \mathrm{H}_{2} / \mathrm{g} \mathrm{VS}$ and $240 \mathrm{~mL} \mathrm{CH}_{4} / \mathrm{g}$ VS, respectively, while COD removal of the process efficiency was 95\% (Han et al., 2005). Chu et al (2008) demonstrated that a temperature-phased two stage process for $\mathrm{H}_{2}$ and $\mathrm{CH}_{4}$ production was more efficient. The yields in thermophilic $\mathrm{H}_{2}$ production and mesophilic $\mathrm{CH}_{4}$ production were $205 \mathrm{~mL} \mathrm{H}_{2} / \mathrm{g}$ VS and $464 \mathrm{~mL} \mathrm{CH}_{4} / \mathrm{g}$ VS, respectively, while COD removal efficiency reached 93\%. The reason of obtaining high $\mathrm{H}_{2}$ yield over $200 \mathrm{~mL} \mathrm{H}_{2} / \mathrm{g}$ VS in above studies was that carbohydrate-rich FW was synthetically collected and used, which is not realistic. Two types of $\mathrm{CH}_{4}$ fermenter were applied for the treatment of dark fermentation effluent (DFE), where anaerobic sequencing batch reactor (ASBR) showed higher bioenergy recovery performance than up-flow anaerobic sludge blanket reactor (UASB) (Jung et al., 2013). However, the maximum OLR and $\mathrm{CH}_{4}$ production rate were approximately three times higher, and the HRT was 7.5 times shorter in the UASB as compared to the ASBR. More energy gain and pollutant removal can significantly increase energy selling and treatment income. However, the additional costs for the construction and operation of the $\mathrm{CH}_{4}$ fermenter should be considered.

An additional advantage of a sequential $\mathrm{CH}_{4}$ fermentation system is that the methanogenic effluent can be utilized as diluting water in $\mathrm{H}_{2}$ fermentation. Jung et al. (2013) and Kraemer and 
Bagley (2005) reported that recycling of $\mathrm{CH}_{4}$ fermented effluent reduced the required amount of alkaline addition for $\mathrm{pH}$ control by approximately 40-50\%. Lee et al. (2010 a) successfully adjusted the $\mathrm{pH}$ at 5.0-5.5 by returning sludge as an alkali buffer without the addition of any external chemical buffer.

\section{FUTURE PERSPECTIVES}

Reports on pilot- and full-scale studies on dark fermentation of FW are quite limited. Fermenter size ranged $0.15-0.5 \mathrm{~m}^{3}$, which was far smaller than the practical size (Cavinato et al., 2012; Jayalakshmi et al., 2009; Lee and Chung, 2010). Homogeneity can be guaranteed with sufficient agitation in a lab-scale fermenter, enabling precise $\mathrm{pH}$ control. However, when scalingup and in practical implementation, it is uncertain whether the $\mathrm{pH}$ would be uniform throughout the fermenter (Amanullah et al., 2001). A dead zone may exist with insufficient agitation, and this phenomenon may lower the accuracy of $\mathrm{pH}$ control, which, in turn, causes a decrease in $\mathrm{H}_{2}$ production (Moon et al., 2015). For the design of an agitator and efficient mixing, it is important to be well informed of rheological properties such as viscosity, storage, and loss moduli. These are not constant values, which varies depending on the solid concentration, temperature, shear rate, and the type of feedstock (Dai et al., 2014; Eshtiaghi et al., 2016). Numerous works have been done on anaerobic digestion sludge, sewage sludge, and digested slurry, but little information is available on dark fermentation.

As previously mentioned, one of the biggest obstacles for the practical application of dark fermentation of $\mathrm{FW}$ is the low $\mathrm{H}_{2}$ yield. A few attempts were made to produce $\mathrm{H}_{2}$ from lipid wastes, but the yields were still low, approximately one third of those from carbohydrates (Liu et al., 2013; Trchounian et al., 2015). Genetic modification such as by knocking out genes related to 
non $\mathrm{H}_{2}$-producing pathways in the degradation of proteins and lipids can increase the $\mathrm{H}_{2}$ yield. However, the use of pure culture in treating actual wastes such as FW is not economically promising (Kleerebezem and van Loosdrecht, 2007).

Although the $\mathrm{H}_{2}$ yield from FW is limited, DFE can be further utilized for valuable fuel and chemical processing (Fig. 1). After successful dark fermentation of FW, short-chain fatty acids (SCFAs) including acetate and butyrate remain, representing $40-60 \%$ of the energy content of FW. These SCFAs can be further processed to $\mathrm{H}_{2}$ by MEC and photo-fermentation. Extensive studies have been carried out on the combined process of "dark- and photo-fermentation" to achieve high $\mathrm{H}_{2}$ yield, but the research on using FW as a feedstock is limited (Zong et al., 2009). Kim and Kim (2013) fermented FW to lactate using the indigenous LAB, and then the supernatant obtained through centrifugation of latctate-fermented residue was converted to $\mathrm{H}_{2}$ by a photo-fermenting organism. A high $\mathrm{H}_{2}$ yield of $8.35 \mathrm{~mol} \mathrm{H}_{2} / \mathrm{mol}$ hexose was attained by photofermentation, which was equivalent to $41 \%$ of the energy content in FW. This was the highest $\mathrm{H}_{2}$ yield ever obtained from FW. However, the low reaction rate of photo-fermentation, which requires a large reactor and footprint can lower the economic feasibility of the integrated system. The possible route to get more $\mathrm{H}_{2}$ by MEC was mentioned in section '4.1' in detail.

The produced SCFAs can be further converted to liquid biofuels including medium-chain fatty acids (MCFAs) and biodiesel by microalgae growth. Acetate, lactate, and propionate, which are the possible soluble metabolites of dark fermentation, have been biologically elongated to MCFAs such as caprylate and heptanoate (Grootscholten et al., 2013; Kucek et al., 2016; Steinbusch et al., 2011). These have higher energy densities and lower solubilities in water due to their longer hydrocarbon tails, which enable selective separation from the broth. MCFAs can be utilized directly as animal feed, green antimicrobials, or corrosion inhibitors, or indirectly by 
conversion with organic chemistry into biofuels such as biodiesel or jet fuels (Spirito et al., 2014). DFE has been tested for the growth of lipid-rich microalgae, and there was a consensus that microalgae growth is favored on effluents containing high acetate concentration rather than butyrate (Turon et al., 2016). Coupling of dark fermentation and heterotrophic microalgae cultivation seems to be a promising sustainable approach for producing both gaseous and liquid biofuels. However, finding an economically feasible means for harvesting and extracting lipid from microalgae still remains a technical challenge (Kim et al., 2013).

On the other hand, the SCFAs in DFE themselves have own values; they can be applied in the food processing, chemical, and pharmaceutical industries. The price of acetic acid and butyric acid ranges $0.4-0.8 \$ / \mathrm{kg}$ and $2.0-2.5 \$ / \mathrm{kg}$, respectively, depending on the purity and grade (Zacharof and Lovitt, 2013). Since SCFAs are highly soluble, their concentration should be high in order to achieve high extraction yield from the broth (Kim et al., 2016). However, the concentrations of acetate and butyrate in DFE were generally below $50 \mathrm{~g} \mathrm{COD} / \mathrm{L}$ due to production inhibition (Kim et al., 2014; Zhu and Yang, 2003). Moreover, in batch operation, the inhibitory effect becomes larger as fermentation proceeds with $\mathrm{pH}$ decrease. At low $\mathrm{pH}$, the proportion of undissociated form of SCFAs increases, which has higher toxicity compared to the dissociated form. The other possible candidate of chemical that can be derived from DFE is polyhydroxyalkanoates (PHAs). It is biodegradable and biocompatible, and is currently widely applied in polymers, pharmaceuticals, and fermentation industries. There have been several attempts to produce both $\mathrm{H}_{2}$ and PHAs from carbohydrate substances, but not from FW (Luongo et al., 2017; Yan et al., 2010).

As described above, dark fermentation can be integrated with various technologies to maximize the value of by-products from FW. It is also essential to generate energy from the solid 
part of DFE by conventional anaerobic digestion. The solid part generally accounts for $30-50 \%$ of energy content of DFE, and the derived $\mathrm{CH}_{4}$ can be utilized for heat and electricity generation, or directly supplied to households and vehicles after upgrading (Kim et al., 2016). This additional energy production can also supplement the energy requirement in the processing of fuels and chemicals from DFE.

\section{SUMMARY}

Compared to other organic solid wastes, higher $\mathrm{H}_{2}$ production potential and rate are generally achievable from FW by dark fermentation. Numerous studies have been conducted to maximize $\mathrm{H}_{2}$ yield and VHPR, but its economic feasibility is still found to be questionable, due to the limited carbohydrate content, thermodynamic limitations, and unwanted fermentation led by indigenous LAB. Attempts have been made to further increase $\mathrm{H}_{2}$ yield and energy recovery by coupling with MECs and methane fermentation. There are several possible routes to utilize DFE for valuable fuel and chemical processing, which can maximize the value of by-products from FW.

\section{ACKNOWLEDGEMENT}

This work was supported by the National Research Foundation of Korea (NRF) grant funded by the Korean Government (MSIP: Ministry ofScience, ICT and Future Planning) (NRF2015R1C1A1A02037289).

\section{REFERENCES}

1. Amanullah A., McFarlane, C.M., Emery, A.N., Nienow, A.W., 2001. Scale-down model to 
simulate spatial pH variations in large-scale bioreactors. Biotechnol. Bioeng. 73, 390-399.

2. Antonopoulou, G., Stamatelatou, K., Venetsaneas, N., Kornaros, M., Lyberatos, G., 2008.

Biohydrogen and methane production from cheese whey in a two-stage anaerobic process. Ind. Eng. Chem. Res. 47, 5227-5233.

3. Asian Institute of Technology, 2010. Municipal waste management report. AIT/UNEP Regional Resource Center for Asia and the Pacific.

4. Bartels, J.R., Pate, M.B., Olson, N.K., 2010. An economic survey of hydrogen production from conventional and alternative energy sources. Int. J. Hydrogen Energ. 35, 8371-8384.

5. Benermann, F.R., 1998. Process analysis and economics of biophotolysis of water. Report to the International Energy Agency Hydrogen Program, Subtask B, Annex 10, Photoproduction of Hydrogen, IEA/H2/10/TR2-98.

6. Breunig, H.M., Jin, L., Robinson, A., Scown, C.D., 2017. Bioenergy potential from food waste in California. Environ. Sci. Technol. 51, 1120-1128.

7. Castillo-Hernandez, A., Mar-Alvarez, I., Moreno-Andrade, I., 2015. Start-up and operation of continuous stirred-tank reactor for biohydrogen production from restaurant organic solid waste. Int. J. Hydrogen Energ. 40, 17239-17245.

8. Cavinato, C., Giuliano, A., Bolzonella, D., Pavan, P., Cecchi, F., 2012. Bio-hydrogen production from food waste by dark fermentation coupled with anaerobic digestion process: A long-term pilot scale experience. Int. J. Hydrogen Energ. 37, 11549-11555.

9. Chu, C.F., Li, Y.Y., Xu, K.Q., Ebie, Y., Inamori, Y., Kong, H.N., 2008. A pH-and temperaturephased two-stage process for hydrogen and methane production from food waste. Int. J. Hydrogen Energ. 33, 4739-4746.

10. Cooney, M., Maynard, N., Cannizzaro, C., Benemann, J., 2007. Two-phase anaerobic 
digestion for production of hydrogen-methane mixtures. Bioresource Technol. 98, 26422651.

11. Cusick, R.D., Bryan, B., Parker, D.S., Merrill, M.D., Mehanna, M., Kiely, P.D., Liu, G., Logan, B.E., 2011. Performance of a pilot-scale continuous flow microbial electrolysis cell fed winery wastewater. Appl. Microbiol. Biotechnol. 89, 2053-2063.

12. Dai, X., Gai, X., Dong, B., 2014. Rheology evolution of sludge through high-solid anaerobic digestion. Bioresource Technol. 174, 6-10.

13. Dhar, B.R., Elbeshbishy, E., Hafez, H., Lee, H.S., 2015. Hydrogen production from sugar beet juice using an integrated biohydrogen process of dark fermentation and microbial electrolysis cell. Bioresource Technol. 198, 223-230.

14. Dong, L., Zhenhong, Y., Yongming, S., Xiaoying, K., Yu, Z., 2009. Hydrogen production characteristics of the organic fraction of municipal solid wastes by anaerobic mixed culture fermentation. Int. J. Hydrogen Energ. 34, 812-820.

15. ElMekawy, A., Srikanth, S., Bajracharya, S., Hegab, H.M., Nigam, P.S., Singh, A., Mohan, S.V., Pant, D., 2015. Food and agricultural wastes as substrates for bioelectrochemical system (BES): The synchronized recovery of sustainable energy and waste treatment. Food Res. Int. 73, 213-225.

16. Eshtiaghi, N., Markis, F., Zain, D., Mai, K.H., 2016. Predicting the apparent viscosity and yield stress of digested and secondary mixtures. Water Res. 95, 159-164.

17. Ewan, B.C.R., Allen, R.W.K., 2005. A figure of merit assessment of the routes to hydrogen. Int. J. Hydrogen Energ. 30, 809-819.

18. Gim, B.J., Kim, J.W., Park, S.Y., 2008. Economic evaluation of hydrogen production by fermentation. Trans. of the Korean hydrogen and new energy society. 19, 145-155. 
19. Grootscholten, T.I.M., Steinbusch, K.J.J., Hamelers, H.V.M, Buisman, C.J.N., 2013. High rate heptanoate production from propionate and ethanol using chain elongation. Bioresource Technol. 136, 715-718.

20. Han, S.K., Kim, S.H., Kim, H.W., Shin, H.S., 2005. Pilot-scale two-stage process: a combination of acidogenic hydrogenesis and methanogenesis. Water Sci. Technol. 52, 131138.

21. Han, S.K., Shin, H.S., 2004. Biohydrogen production by anaerobic fermentation of food waste. Int. J. Hydrogen Energ. 29, 569-577.

22. Han, W., Fang, J., Liu, Z.X., Tang, J.H., 2016a. Techno-economic evaluation of a combined bioprocess for fermentative hydrogen production from food waste. Bioresource Technol. 202, 107-112.

23. Han, W., Yan, Y.T., Gu, J.J., Shi, Y.W., Tang, J.H., Li, Y.F., 2016b. Techno-economic analysis of a novel bioprocess combining solid state fermentation and dark fermentation for $\mathrm{H}_{2}$ production from food waste. Int. J. Hydrogen Energ. 41, 22619-22625.

24. Heyndrickx, M., Vos, P.D., Vancanneyt, M., Ley, J.D., 1991. The fermentation of glycerol by Clostridium butyricum LMG $1212 \mathrm{t} 2$ and $1213 \mathrm{t} 1$ and $C$. pasteurianum LMG 3285. Appl. Microbiol. Biotechnol. 32, 637-647.

25. Im, W.T., Kim, D.H., Kim, K.H., Kim, M.S., 2012. Bacterial community analyses by pyrosequencing in dark fermentative $\mathrm{H}_{2}$-producing reactor using organic wastes as a feedstock. Int. J. Hydrogen Energ. 37, 8330-8337.

26. Jang, S., Kim, D.H., Yun, Y.M., Lee, M.K., Moon, C., Kang, W.S., Kwak, S.S., Kim, M.S., 2015. Hydrogen fermentation of food waste by alkali-shock pretreatment: Microbial community analysis and limitation of continuous operation. Bioresource Technol. 186, 215- 
222.

27. Jayalakshmi, S., Joseph, K., Sukumaran, V., 2009. Biohydrogen generation from kitchen waste in an inclined plug flow reactor. Int. J. Hydrogen Energ. 34, 8854-8858.

28. Jo, J.H., Jeon, C.O., Lee, D.S., Park, J.M., 2007. Process stability and microbial community structure in anaerobic hydrogen-producing microflora from food waste containing kimchi. J. Biotechnol. 131, 300-308.

29. Jung, K.W., Moon, C., Cho, S.K., Kim, S.H., Shin, H.S., Kim, D.H., 2013. Conversion of organic solid waste to hydrogen and methane by two-stage fermentation system with reuse of methane fermenter effluent as diluting water in hydrogen fermentation. Bioresource Technol. 139, 120-127.

30. Kim, D.H., Jang, S., Yun, W.M., Lee, M.K., Moon, C., Kang, W.S., Kim, M.S., 2014. Effect of acid-pretreatment on hydrogen fermentation of food waste: Microbial community analysis by next generation sequencing. Int. J. Hydrogen Energ. 39, 16302-16309.

31. Kim, D.H., Kim, M.S., 2011. Hydrogenases for biological hydrogen production. Bioresource Technol. 102, 8423-8431.

32. Kim, D.H., Kim, M.S., 2013. Development of a novel three-stage fermentation system converting food waste to hydrogen and methane. Bioresource Technol. 127, 267-274.

33. Kim, D.H., Kim, S.H., Jung, K.W., Kim, M.S., Shin, H.S., 2011a. Effect of initial pH independent of operational $\mathrm{pH}$ on hydrogen fermentation of food waste. Bioresource Technol. 102, 8646-8652.

34. Kim, D.H., Kim, S.H., Kim, K.Y., Shin, H.S. 2010. Experience of a pilot-scale hydrogenproducing anaerobic sequencing batch reactor (ASBR) treating food waste. Int. J. Hydrogen Energ. 35, 1590-1594. 
35. Kim, D.H., Kim, S.H., Kim, H.W., Kim, M.S., Shin, H.S., 2011b. Sewage sludge addition to food waste synergistically enhances hydrogen fermentation performance. Bioresource Technol. 102, 8501-8506.

36. Kim, D.H., Kim, S.H., Shin, H.S., 2009. Hydrogen fermentation of food waste without inoculum addition. Enzyme Microb. Tech. 45, 181-187.

37. Kim, D.H., Lee, J.H., Hwang, Y., Kang, S., Kim, M.S., 2013. Continuous cultivation of photosynthetic bacteria for fatty acids production. Bioresource Technol. 148, 277-282.

38. Kim, D.H., Wu, J., Jeong, K.W., Kim, M.S., Shin, H.S., 2011c. Natural inducement of hydrogen from food waste by temperature control. Int. J. Hydrogen Energ. 36, 10666-10673.

39. Kim, M.S., Na, J.G., Lee, M.K., Ryu, H., Chang, Y.K., Triolo, J.M., Yun, Y.M., Kim, D.H., 2016. More value from food waste: Lactic acid and biogas recovery. Water Res. 96, 208-216.

40. Kim, S.H., Han, S.K., Shin, H.S., 2004. Feasibility of biohydrogen production by anaerobic co-digestion of food waste and sewage sludge. Int. J. Hydrogen Energ. 29, 1607-1616.

41. Kim, S.H., Han, S.K., Shin, H.S., 2008. Optimization of continuous hydrogen fermentation of food waste as a function of solids retention time independent of hydraulic retention time. Process Biochem. 43, 213-218.

42. Kleerebezem, R., van Loosdrecht M.C.M., 2007. Mixed culture biotechnology for bioenergy production. Curr. Opin. Biotech. 18, 207-212.

43. Kraemer, J.T., Bagley, D.M., 2005. Continuous fermentative hydrogen production using a two-phase reactor system with recycle. Environ. Sci. Technol. 39, 3819-3825.

44. Kucek, L.A., Nguyen, M., Angenent, L.T., 2016. Conversion of L-lactate into n-caproate by a continuously fed reactor microbiome. Water Res. 93, 163-171.

45. Kumar, G., Bakonyi, P., Kobayashi, T., Xu, K.-Q., Sivagurunathan, P., Kim, S.-H., Buitrón, 
G., Nemestóthy, N., Bélafi-Bakó, K., 2016. Enhancement of biofuel production via microbial augmentation: The case of dark fermentative hydrogen. Renew. Sustain. Energy Rev. 57, $879-891$.

46. Lalaurette, E., Thammannagowda, S., Mohagheghi, A., Maness, P.-C., Logan, B.E., 2009. Hydrogen production from cellulose in a two-stage process combining fermentation and electrohydrogenesis. Int. J. Hydrogen Energ. 34, 6201-6210.

47. Lalman, J.A., Chaganti, S.R., Moon, C., Kim, D.H., 2013. Elucidating acetogenic $\mathrm{H}_{2}$ consumption in dark fermentation using flux balance analysis. Bioresource Technol. 146, $775-778$.

48. Lay, J.J., Fan, K.S., Chang, J., Ku, C.H., 2003. Influence of chemical nature of organic wastes on their conversion to hydrogen by heat-shock digested sludge. Int. J. Hydrogen Energ. 28, 1361-1367.

49. Lee, D.Y., Ebie, Y., Xu, K.Q., Li, Y.Y., Inamori, Y., 2010a. Continuous $\mathrm{H}_{2}$ and $\mathrm{CH}_{4}$ production from high-solid food waste in the two-stage thermophilic fermentation process with the recirculation of digester sludge. Bioresource Technol. 101, S42-S47.

50. Lee, D.Y., Xu, K.Q., Kobayashi, T., Li, Y.Y., Inamori, Y., 2014. Effect of organic loading rate on continuous hydrogen production from food waste in submerged anaerobic membrane bioreactor. Int. J. Hydrogen Energ. 39, 16863-16871.

51. Lee, Y.W., Chung, J., 2010. Bioproduction of hydrogen from food waste by pilot-scale combined hydrogen/methane fermentation. Int. J. Hydrogen Energ. 35, 11746-11755.

52. Lee, Z.K., Li, S.L., Kuo, P.C., Chen, I.C., Tien, Y.M., Huang, Y.J., Chuang, C.P., Wong, S.C., Cheng, S.S., 2010b. Thermophilic bio-energy process study on hydrogen fermentation with vegetable kitchen waste. Int. J. Hydrogen Energ. 35, 13458-13466. 
53. Li, S.L., Kuo, S.C., Lin, J.S., Lee, Z.K., Wang, Y.H., Cheng, S.S., 2008. Process performance evaluation of intermittent-continuous stirred tank reactor for anaerobic hydrogen fermentation with kitchen waste. Int. J. Hydrogen Energ. 33, 1522-1531.

54. Liu, B., Christiansen, K., Pamas, R., Xu, Z., Li, B., 2013. Optimizing the production of hydrogen and 1,3-propanediol in anaerobic fermentation of biodiesel glycerol. Int. J. Hydrogen Energ. 38, 3196-3205.

55. Li, Y.C., Liu, Y.F., Chu, C.Y., Chang, P.L., Hsu, C.W., Lin, P.J., Wu, S.Y., 2012. Technoeconomic evaluation of biohydrogen production from wastewater and agricultural waste. Int. J. Hydrogen Energ. 37, 15704-15710.

56. Luccio, M.D., Borges, C.P., Alves, T.L.M., 2002. Economic analysis of ethanol and fructose production by selective fermentation coupled to pervaporation: effect of membrane costs on process economics. Desalination 147, 161-166.

57. Lu, L., Ren, N., Xing, D., Logan, B.E., 2009. Hydrogen production with effluent from an ethanol- $\mathrm{H}_{2}$-coproducing fermentation reactor using a single-chamber microbial electrolysis cell. Biosens. Bioelectron. 24, 3055-3060.

58. Luongo, V., Ghimire, A., Frunzo, L., Fabbricino, M., d’Antonio, G., Pirozzi, F., Esposito, G., 2017. Photofermentative production of hydrogen and ploy- $\beta$-hydroxybutyrate from dark fermentation products. Bioresource Technol. 228, 171-175.

59. Marone, A., Ayala-Campos, O.R., Trably, E., Carmona-Martinez, A.A., Moscoviz, R., Latrille, E., Steyer, J., Alcaraz-Gonzalez, V., Bernet, N., 2017. Coupling dark fermentation and microbial electrolysis to enhance bio-hydrogen production from agro-industrial wastewaters and by-products in a bio-refinery framework. Int. J. Hydrogen Energ. 42, 19091621. 
60. Montpart, N., Rago, L., Baeza, J.A., Guisasola, A., 2014. Hydrogen production in single chamber microbial electrolysis cells with different complex substrates. Water Res. 68, 601615.

61. Moon, C., Jang, S., Yun, Y.M., Lee, M.K., Kim, D.H., Kang, W.S., Kwak, S.S., Kim, M.S., 2015. Effect of the accuracy of pH control on hydrogen fermentation. Bioresource Technol. 179, 595-601.

62. Moreno, R., Escapa, A., Cara, J., Carracedo, B., Gómez, X., 2015. A two-stage process for hydrogen production from cheese whey: Integration of dark fermentation and biocatalyzed electrolysis. Int. J. Hydrogen Energ. 40, 168-175.

63. National Assembly Budget Office, 2012. Biogas business assessment in Korea.

64. Noike, T., Takabatake, H., Mizuno, O., Ohba, M., 2002. Inhibition of hydrogen fermentation of organic wastes by lactic acid bacteria. Int. J. Hydrogen Energ. 27, 1367-1371.

65. Oh, Y.K., Kim, Y.J., Kim, M.S., Park, S.H., 2006. Economic evaluation of two-step biohydrogen/biomethane production process. Trans. of the Korean hydrogen and new energy society $17,98-108$.

66. Okamoto, M., Miyahara, T., Mizuno, O., Noike, T., 2000. Biological hydrogen potential of materials charateristic of the organic fraction of municipal solid wastes. Water Sci. Technol. $41,25-32$.

67. Pan, J., Zhang, R., El-Mashad, H.M., Sun, H., Ying, Y., 2008. Effect of food to microorganism ratio on biohydrogen production from food waste via anaerobic fermentation. Int. J. Hydrogen Energ. 33, 6968-6975.

68. Paudel, S., Kang, Y.J., Yoo, Y.S., Seo, G.T., 2017. Effect of volumetric organic loading rate (OLR) on $\mathrm{H}_{2}$ and $\mathrm{CH}_{4}$ production by two-stage anaerobic co-digestion of food waste and 
brown water. Waste Manage. 61, 484-493.

69. Rago, L., Baeza, J.A., Guisasola, A., 2017. Bioelectrochemical hydrogen production with cheese whey as sole substrate. J. Chem. Technol. Biotechnol. 92, 173-179.

70. Shin, H.S., Youn, J.H., Kim, S.H., 2004. Hydrogen production from food waste in anaerobic mesophilic and thermophilic acidogenesis. Int. J. Hydrogen Energ. 29, 1355-1363.

71. Sosa-hernández, O., Popat, S.C., Parameswaran, P., Alemán-nava, G.S., Torres, C.I., Buitrón, G., Parra-saldívar, R., 2016. Application of microbial electrolysis cells to treat spent yeast from an alcoholic fermentation. Bioresource Technol. 200, 342-349.

72. Spirito, C.M., Richter, H., Rabaey, K., Stams, A.J.M., Angenent, L.T., 2014. Chain elongation in anaerobic reactor microbiomes to recover resources from waste. Curr. Opin. Biotech. 27, 115-122.

73. Sreela-or, C., Plangklang, P., Imai, T., Reungsang, A., 2011. Co-digestion of food waste and sludge for hydrogen production by anaerobic mixed cultures: Statistical key factors optimization. Int. J. Hydrogen Energ. 36, 14227-14237.

74. Steinbusch, K.J.J., Hamelers, H.V.M., Plugge, C.M., Buisman, C.J.N., 2011. Biological formation of caproate and caprylate from acetate: fuel and chemical production from low grade biomass. Energy Environ. Sci. 4, 216-224.

75. Stiles, M.E., Holzapfel, W.H., 1997. Lactic acid bacteria of foods and their current taxonomy. Int. J. Food Microbiol. 36, 1-29.

76. Tawfik, A., El-Qelish, M., 2012. Continuous hydrogen production from co-digestion of municipal food waste and kitchen wastewater in mesophilic anaerobic baffled reactor. Bioresource Technol. 114, 270-274.

77. Trchounian, K., Abrahamyan, V., Poladyan, A., Trchounian, A., 2015. Escheriachia coli 
growth and hydrogen production in batch culture upon formate alone and with glycerol cofermentation at different pHs. Int. J. Hydrogen Energ. 40, 9935-9941.

78. Turon, V., Trably, E., Fouilland, E., Steyer, J.P., 2016. Potentialities of dark fermentation effluents as substrates for microalgae growth: A review. Process Biochem. 51, 1843-1854.

79. Van Haandel, A.C., Lettinga, G., 1994. Anaerobic sewage treatment: A practical guide for regions with a hot climate. John Wiley \& Sons Inc., New York.

80. Vrije, T.D., Claassen, P.A.M., 2003. Dark hydrogen fermentations, in: J.H. Reith, R.H. Wijffels, H. Barten (Eds.), Bio-methane \& Bio-hydrogen: Status and perspectives of biological methane and hydrogen production. Dutch Biological Hydrogen Foundation., Netherlands, pp. 103-123.

81. Wang, X., Zhao, Y.C., 2009. A bench scale study of fermentative hydrogen and methane production from food waste in integrated two-stage process. Int. J. Hydrogen Energ. 34, 245-254.

82. Wang, Y., Guo, W., Xing, D., Chang, J., 2014. Hydrogen production using biocathode single- chamber microbial electrolysis cells fed by molasses wastewater at low temperature. Int. J. Hydrogen Energ. 39, 19369-19375.

83. Wu, S.Y., Hung, C.H., Lin, C.N., Chen, H.W., Lee, A.S., Chang, J.S., 2006. Fermentative hydrogen production and bacterial community structure in high-rate anaerobic bioreactors containing silicone-immobilized and self-flocculated sludge. Biotechnol. Bioeng. 93, 934946.

84. Xiao, L., Deng, Z., Fung, K.Y., Ng, K.M., 2013. Biohydrogen generation from anaerobic digestion of food waste. Int. J. Hydrogen Energ. 38, 13907-13913.

85. Yan, Q., Zhao, M., Miao, H., Ruan, W., Song, R., 2010. Coupling of the hydrogen and 
polyhydroxyalkanoates (PHA) production through anaerobic digestion from Taihu blue algae. $101,4508-4512$.

86. Zacharof, M.P., Lovitt, R.W. 2013, Complex effluent streams as a potential source of volatile fatty acids. Waste Biomass Valor. 4, 557-581.

87. Zhou, P., Elbeshbishy, E., Nakhla, G., 2013. Optimization of biological hydrogen production for anaerobic co-digestion of food waste and watewater biosolids. Bioresource Technol. 130, 710-718.

88. Zhu, Y., Yang, S.T., 2003. Adaptation of Clostridium tyrobutyricum for enhanced tolerance to butyric acid in a fibrous bed bioreactor. Biotechnol. Prog. 19, 365-372.

89. Zong, W., Yu, R., Zhang, P., Fan, M., Zhou, Z., 2009. Efficient hydrogen gas production from cassava and food waste by a two-step process of dark fermentation and photofermentation. Biomass Bioenerg. 33, 1458-1463. 
Fig. 1 Integrated system of dark fermentation of food waste with effluent conversion process $($ SCFAs $=$ Short-chain fatty acids, MEC $=$ Microbial electrolysis cells, MCFAs $=$ Medium-chain fatty acids, PHAs = Polyhydroxyalkanoates)

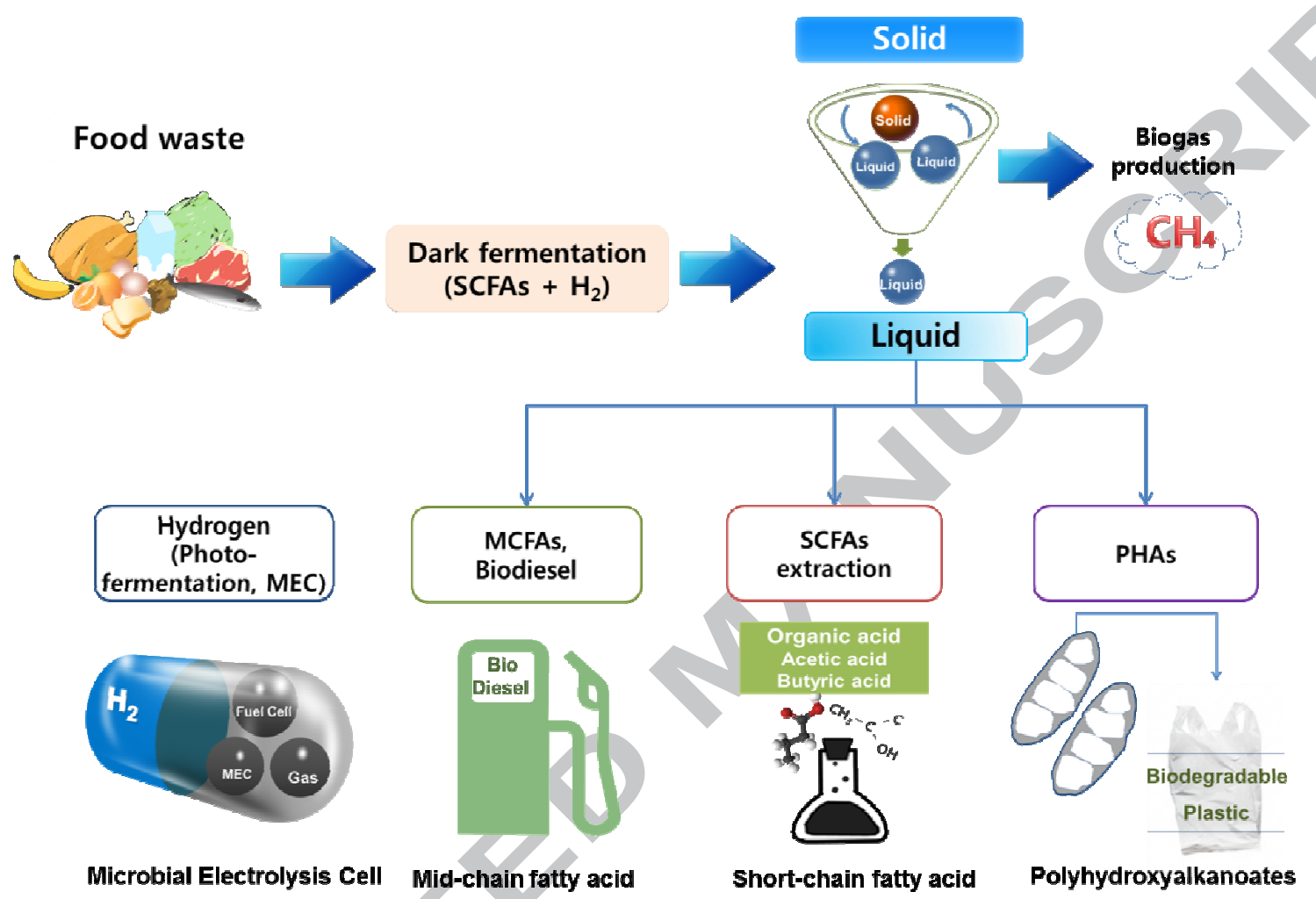


Table 1 Batch $\mathrm{H}_{2}$ production performance from food waste by dark fermentation (The $\mathrm{H}_{2}$ yield value indicated here was obtained under optimal condition.)

\begin{tabular}{|c|c|c|c|c|}
\hline $\begin{array}{c}\text { Substrate } \\
\text { concentration }\end{array}$ & Temp. & $\mathrm{H}_{2}$ yield per added substrate & Strategy to enhance performance & Reference \\
\hline $\begin{array}{c}30 \text { g Carbo. } \\
\text { COD/L }\end{array}$ & $35^{\circ} \mathrm{C}$ & $2.26 \mathrm{~mol} \mathrm{H}_{2} / \mathrm{mol}$ hexose & Heat-treatment $\left(90^{\circ} \mathrm{C}\right.$ for $\left.20 \mathrm{~m}\right)$ & Im et al. (2012) \\
\hline $\begin{array}{c}30 \text { g Carbo. } \\
\text { COD/L }\end{array}$ & $35^{\circ} \mathrm{C}$ & $153.5 \mathrm{~mL} \mathrm{H}_{2} / \mathrm{g} \mathrm{VS}$ & $\begin{array}{l}\text { Heat- }\left(90^{\circ} \mathrm{C} \text { for } 20 \mathrm{~m}\right) \text {, acid- }(\mathrm{pH} 1 \text { for } 1 \mathrm{~d}) \text {, } \\
\quad \text { and alkali-treatment (pH } 13 \text { for } 1 \mathrm{~d})\end{array}$ & $\begin{array}{l}\text { Kim et al. } \\
\text { (2009) }\end{array}$ \\
\hline $\begin{array}{c}30 \text { g Carbo. } \\
\text { COD/L }\end{array}$ & $35^{\circ} \mathrm{C}$ & $1.74 \mathrm{~mol} \mathrm{H}_{2} / \mathrm{mol}$ hexose & Acid-treatment (pH 1.0-4.0) & $\begin{array}{l}\text { Kim et al. } \\
\text { (2014) }\end{array}$ \\
\hline $\begin{array}{c}30 \text { g Carbo. } \\
\text { COD/L }\end{array}$ & $37^{\circ} \mathrm{C}$ & $\begin{array}{c}162 \mathrm{~mL} \mathrm{H}_{2} / \mathrm{g} \mathrm{VS} \\
1.71 \mathrm{~mol} \mathrm{H}_{2} / \mathrm{mol} \text { hexose } \\
133 \mathrm{~mL} / \mathrm{g} \mathrm{COD}\end{array}$ & Alkali-treatment (pH 9-13, 6 h) & $\begin{array}{l}\text { Jang et al. } \\
\text { (2015) }\end{array}$ \\
\hline $\begin{array}{c}30 \text { g Carbo. } \\
\text { COD/L }\end{array}$ & $35^{\circ} \mathrm{C}$ & $1.92 \mathrm{~mol} \mathrm{H}_{2} / \mathrm{mol} \mathrm{her}$ & Initial $\mathrm{pH}$ change (5.0-9.0) & $\begin{array}{l}\text { Kim et al. } \\
\qquad\left(2011^{\mathrm{a}}\right)\end{array}$ \\
\hline N.A. ${ }^{a}$ & $37^{\circ} \mathrm{C}$ & 77.0-79.1 $\mathrm{mL} \mathrm{H}_{2} / \mathrm{g} \mathrm{VS}$ & Initial $\mathrm{pH}$ change $(5,6,8)$ & $\begin{array}{l}\text { Xiao et al. } \\
\text { (2013) }\end{array}$ \\
\hline $\begin{array}{l}5-80 \mathrm{~g} \\
\text { Carbo. } \\
\text { COD/L }\end{array}$ & $35^{\circ} \mathrm{C}$ & $1.71 \mathrm{~mol} \mathrm{H}_{2} / \mathrm{mol}$ hexose & $\begin{array}{l}\text { Substrate concentration change } \\
\qquad(5-80 \text { g Carbo. COD/L) }\end{array}$ & $\begin{array}{l}\text { Kim et al. } \\
\text { (2014) }\end{array}$ \\
\hline $\begin{array}{c}30 \text { g Carbo. } \\
\text { COD/L }\end{array}$ & & $1.79 \mathrm{~mol} \mathrm{H}_{2} / \mathrm{mol}$ hexose & Temperature change $\left(35-60^{\circ} \mathrm{C}\right)$ & $\begin{array}{l}\text { Kim et al. } \\
\left(2011^{\mathrm{c}}\right)\end{array}$ \\
\hline $\begin{array}{r}30 \mathrm{~g} \\
\mathrm{CC}\end{array}$ & $35^{\circ} \mathrm{C}$ & $2.11 \mathrm{~mol} \mathrm{H}_{2} / \mathrm{mol}$ hexose & $\begin{array}{c}\text { Co-digestion } \\
\left(\mathrm{FW}: \mathrm{SWS}^{\mathrm{a}}=10: 0-10: 4,0: 10\right),\end{array}$ & $\begin{array}{l}\text { Kim et al. } \\
\left(2011^{\mathrm{b}}\right)\end{array}$ \\
\hline N.A. ${ }^{a}$ & $37^{\circ} \mathrm{C}$ & $102.63 \mathrm{~mL} \mathrm{H}_{2} / \mathrm{g} \mathrm{VS}$ & $\begin{array}{l}\text { Co-digestion }\left(\mathrm{FW}+\mathrm{SWS}^{\mathrm{b}}\right) \text { at different } \mathrm{C} / \mathrm{N} \\
\quad \text { ratios }(10: 1,20: 1,30: 1,40: 1 \text {, and } 50: 1)\end{array}$ & $\begin{array}{l}\text { Sreela-or et al. } \\
\qquad(2011)\end{array}$ \\
\hline $5-50 \mathrm{~g} \mathrm{VS} / \mathrm{L}$ & $35^{\circ} \mathrm{C}$ & $1.05 \mathrm{~mol} \mathrm{H}_{2} / \mathrm{mol}$ hexose & $\begin{array}{l}\text { Co-digestion at various substrate } \\
\text { concentration } \\
\left.\text { (FW:SWS }{ }^{\mathrm{b}}=0: 100-100: 0\right)\end{array}$ & $\begin{array}{l}\text { Kim et al. } \\
\text { (2004) }\end{array}$ \\
\hline
\end{tabular}




\begin{tabular}{|c|c|c|c|c|}
\hline \multirow[b]{2}{*}{ N.A. ${ }^{a}$} & & $76 \mathrm{~mL} \mathrm{H}_{2} / \mathrm{g} \mathrm{COD}$ & & \multirow[b]{2}{*}{$\begin{array}{c}\text { Zhou et al. } \\
\text { (2013) }\end{array}$} \\
\hline & $37^{\circ} \mathrm{C}$ & $\begin{array}{c}165 \mathrm{~mL} \mathrm{H}_{2} / \mathrm{g} \mathrm{VS} \\
1.84 \mathrm{~mol} \mathrm{H}_{2} / \mathrm{mol}^{2} \text { hexose }\end{array}$ & Co-digestion $\left(\mathrm{FW}+\mathrm{PS}^{\mathrm{c}}+\mathrm{WAS}^{\mathrm{d}}\right)$ & \\
\hline
\end{tabular}

Table 2 Typical glucose degradation reactions in dark fermentation

\begin{tabular}{ll}
\hline \multicolumn{1}{c}{ Reactions } \\
\hline $\mathrm{H}_{2}$ production & Glucose $+2 \mathrm{H}_{2} \mathrm{O} \rightarrow 2$ Acetate $+2 \mathrm{CO}_{2}+4 \mathrm{H}_{2}$ \\
& Glucose $+\mathrm{H}_{2} \mathrm{O} \rightarrow$ Acetone $+3 \mathrm{CO}_{2}+4 \mathrm{H}_{2}$ \\
\hline No relation & Glucose $\rightarrow$ Butyrate $+2 \mathrm{CO}_{2}+2 \mathrm{H}_{2}$ \\
& Glucose $\rightarrow$ Butanol $+2 \mathrm{CO}_{2}+\mathrm{H}_{2} \mathrm{O}$ \\
& Glucose $\rightarrow 2 \mathrm{Ethanol}+2 \mathrm{CO}_{2}$ \\
\hline & Glucose $+2 \mathrm{H}_{2} \rightarrow 2 \mathrm{Propionate}_{2}+2 \mathrm{H}_{2} \mathrm{O}$ \\
& Glucose $+2 \mathrm{CO}_{2}+2 \mathrm{H}_{2} \rightarrow 2 \mathrm{Succinate}+2 \mathrm{H}_{2} \mathrm{O}$ \\
& $\mathrm{H}_{2}+\mathrm{CO}_{2} \rightarrow$ Formate \\
\hline
\end{tabular}


Table 3 Continuous $\mathrm{H}_{2}$ production performance from food waste by dark fermentation (The VHPR value indicated here was obtained under optimal condition.)

\begin{tabular}{|c|c|c|c|c|c|c|c|}
\hline $\begin{array}{l}\text { Reactor } \\
\text { type }\end{array}$ & $\mathrm{OLR}^{\mathrm{a}}$ & $\mathrm{HRT}^{\mathrm{b}}$ & Temp. & $\begin{array}{c}\mathrm{H}_{2} \text { yield } \\
\text { per added } \\
\text { substrate }\end{array}$ & $\begin{array}{l}\text { VHPR }^{\mathrm{c}} \\
\text { (optimal } \\
\text { condition) }\end{array}$ & $\begin{array}{l}\text { Strategy to enhance } \\
\text { performance }\end{array}$ & Reference \\
\hline & $29.0-47.0$ & & & $12.9 \mathrm{~mL}$ & $0.4 \mathrm{~L} \mathrm{H}_{2} / \mathrm{L} / \mathrm{d}$ & OLR change & \\
\hline $\mathrm{ABR}^{\mathrm{d}}$ & $\begin{array}{c}\mathrm{g} \\
\mathrm{COD} / \mathrm{L} / \mathrm{d}\end{array}$ & $1.6 \mathrm{~d}$ & & 2 & $\begin{array}{c}(29 \mathrm{~g} \\
\mathrm{COD} / \mathrm{L} / \mathrm{d})\end{array}$ & $\begin{array}{c}(29,36,47 \mathrm{~g} \\
\text { COD/L/d) }\end{array}$ & $\begin{array}{l}\text { Tawt1k et al. } \\
\text { (2012) }\end{array}$ \\
\hline $\mathrm{i}-\mathrm{CSTR}^{\mathrm{e}}$ & $\begin{array}{c}19,28 \\
\mathrm{~g} \\
\mathrm{COD} / \mathrm{L} / \mathrm{d}\end{array}$ & & & $\begin{array}{c}38.1 \mathrm{~mL} \\
\mathrm{H}_{2} / \mathrm{g} \text { COD }\end{array}$ & $\begin{array}{c}1.0 \mathrm{~L} \mathrm{H}_{2} / \mathrm{L} / \mathrm{d} \\
(28 \mathrm{~g} \\
\mathrm{COD} / \mathrm{L} / \mathrm{d})\end{array}$ & $\begin{array}{c}\text { OLR change } \\
(19,28 \mathrm{~g} \mathrm{COD} / \mathrm{L} / \mathrm{d})\end{array}$ & $\begin{array}{l}\text { Lee et al. } \\
\left(2010^{\mathrm{b}}\right)\end{array}$ \\
\hline $\begin{array}{l}\text { Membrane } \\
\text { bioreactor }\end{array}$ & $\begin{array}{c}70.2- \\
125.4 \mathrm{~g} \\
\mathrm{COD} / \mathrm{L} / \mathrm{d}\end{array}$ & $\begin{array}{l}18.7 \\
14.0 \\
10.5 \mathrm{~h}\end{array}$ & $55^{\circ} \mathrm{C}$ & $\begin{array}{l}111.1 \mathrm{~mL} \\
\mathrm{H}_{2} / \mathrm{g} \mathrm{VS}\end{array}$ & $\begin{array}{c}10.7 \mathrm{~L} \mathrm{H}_{2} / \mathrm{L} / \mathrm{d} \\
(125.4 \mathrm{~g} \\
\mathrm{COD} / \mathrm{L} / \mathrm{d})\end{array}$ & $\begin{array}{c}\text { OLR change } \\
(70.2,89.4,125.4 \mathrm{~g} \\
\text { COD/L/d })\end{array}$ & $\begin{array}{l}\text { Lee et al. } \\
\text { (2014) }\end{array}$ \\
\hline $\operatorname{CSTR}^{\mathrm{f}}$ & $\begin{array}{l}19.0-57.0 \\
\text { g VS/L/d }\end{array}$ & $24-8 \mathrm{~h}$ & $35^{\circ} \mathrm{C}$ & $\begin{array}{l}11.2 \mathrm{~mL} \\
\mathrm{H}_{2} / \mathrm{g} \mathrm{VS}\end{array}$ & $\begin{array}{c}0.4 \mathrm{~L} \mathrm{H}_{2} / \mathrm{L} / \mathrm{d} \\
(38 \mathrm{~g} \mathrm{VS} / \mathrm{L} / \mathrm{d})\end{array}$ & $\begin{array}{c}\text { OLR change } \\
(19-57 \mathrm{~g} \mathrm{VS} / \mathrm{L} / \mathrm{d})\end{array}$ & $\begin{array}{l}\text { Castillo- } \\
\text { Hernandez } \\
\text { et al. (2015) }\end{array}$ \\
\hline $\mathrm{ASBR}^{\mathrm{g}}$ & $\begin{array}{c}15.4-27.0 \\
\mathrm{~g} \\
\mathrm{COD} / \mathrm{L} / \mathrm{d}\end{array}$ & $\begin{array}{c}42-24 \\
\mathrm{~h}\end{array}$ & $35^{\circ} \mathrm{C}$ & $\begin{array}{c}61.7 \mathrm{~mL} \\
\mathrm{H}_{2} / \\
\mathrm{g} \mathrm{VS}\end{array}$ & $\begin{array}{l}2.7 \mathrm{~L} \mathrm{H}_{2} / \mathrm{L} / \mathrm{d} \\
(\mathrm{HRT} 24 \mathrm{~h}, \\
\text { SRT } 100 \mathrm{~h})\end{array}$ & $\begin{array}{l}\text { HRT change (42-24 } \\
\text { h), SRT change } \\
\quad(160-24 \mathrm{~h})\end{array}$ & $\begin{array}{l}\text { Kim et al. } \\
\text { (2008) }\end{array}$ \\
\hline $\operatorname{CSTR}^{\mathrm{f}}$ & $\begin{array}{c}1.2 \mathrm{~g} \\
\mathrm{VS} / \mathrm{L} / \mathrm{d}\end{array}$ & $5 \mathrm{~d}$ & $\begin{array}{c}35 \\
55^{\circ} \mathrm{C}\end{array}$ & $\begin{array}{c}1.8 \mathrm{~mol} \\
\mathrm{H}_{2} / \\
\text { mol } \\
\text { hexose }\end{array}$ & $\begin{array}{c}0.1 \mathrm{~L} \mathrm{H}_{2} / \mathrm{L} / \mathrm{d} \\
(6 \mathrm{~g} \mathrm{VS} / \mathrm{L} \\
55 \mathrm{oC})\end{array}$ & $\begin{array}{l}\text { VS concentration } \\
\text { change (3-10 g } \\
\text { VS/L), } \\
\text { Temp. comparison }\end{array}$ & $\begin{array}{l}\text { Shin et al. } \\
\text { (2004) }\end{array}$ \\
\hline $\mathrm{ASBR}^{\mathrm{g}}$ & $20 \mathrm{~g}$ & $36 \mathrm{~h}$ & $35^{\circ} \mathrm{C}$ & $0.9 \mathrm{~mol}$ & $2.1 \mathrm{~L} \mathrm{H}_{2} / \mathrm{L} / \mathrm{d}$ & $\mathrm{C} / \mathrm{N}$ ratio change & Kim et al. \\
\hline
\end{tabular}




\begin{tabular}{|c|c|c|c|c|c|c|c|}
\hline & $\begin{array}{c}\text { Carbo. } \\
\text { COD/L/d }\end{array}$ & & & $\begin{array}{c}\mathrm{H}_{2} / \\
\text { mol } \\
\text { hexose }\end{array}$ & $\begin{array}{c}(\mathrm{C} / \mathrm{N} \text { ratio }= \\
20)\end{array}$ & $(10-30)$ & $(2010)$ \\
\hline $\operatorname{CSTR}^{\mathrm{f}}$ & $\begin{array}{l}17.7-106 \\
\mathrm{~g} \mathrm{VS} / \mathrm{L} / \mathrm{d}\end{array}$ & $48-4 \mathrm{~h}$ & $35^{\circ} \mathrm{C}$ & - & $\begin{array}{c}3.5 \mathrm{~L} \mathrm{H}_{2} / \mathrm{L} / \mathrm{d} \\
(\mathrm{HRT} 8 \mathrm{~h})\end{array}$ & $\begin{array}{l}\text { Co-digestion with } \\
\text { brown water, } \\
\text { HRT } 48-8 \mathrm{~h}\end{array}$ & $\begin{array}{l}\text { Paudel et al. } \\
\text { (2017) }\end{array}$ \\
\hline
\end{tabular}

${ }^{\mathrm{a}} \mathrm{OLR}=$ Organic loading rate; ${ }^{b} \mathrm{HRT}=\mathrm{Hydraulic}$ retention time; ${ }^{\mathrm{c}} \mathrm{VHPR}=$ Volumetric $\mathrm{H}_{2}$ production rate; ${ }^{\mathrm{d}} \mathrm{ABR}=$ Anaerobic baffled reactor; ${ }^{\mathrm{e}} \mathrm{i}-\mathrm{CSTR}=$ intermittent-continuously stirred tank reactor; ${ }^{\mathrm{f}} \mathrm{CSTR}=$ continuously stirred tank reactor; ${ }^{\mathrm{g}} \mathrm{ASBR}=$ anaerobic sequencing batch reactor

Table 4 Economic assessment for $\mathrm{H}_{2}$ production from food waste by dark fermentation

\begin{tabular}{|c|c|c|c|}
\hline & Item & $\begin{array}{c}\text { Cost (USD, } \\
\text { USD/y) }\end{array}$ & Reference \\
\hline \multirow{2}{*}{ Capital cost } & Total & $1,636,560$ & \\
\hline & Storage tank ( $25 \%$ of fermenter cost) & 89,000 & Han et al., $2016^{\mathrm{a}}$ \\
\hline \multirow{2}{*}{ Construction } & $\mathrm{H}_{2}$ fermenter & 356,000 & Vrije and Claassen., 2013 \\
\hline & Food waste grinding, Heat exchanger & 258,000 & Han et al., 2016 \\
\hline \multirow[b]{2}{*}{ Additional } & Purification (PSA/Fermenter ratio: 1.09) & 388,040 & Gim et al., 2008 \\
\hline & $\begin{array}{c}\text { Land use, set up } \\
\text { (50\% of construction cost) }\end{array}$ & 545,520 & Van and Lettinga, 1994 \\
\hline Operation cost & Total & 548,568 & \\
\hline Materials & Chemicals & 48,000 & Oh et al., 2006 \\
\hline Maintenance & $6 \%$ of capital cost & 98,194 & Benemann et al., 1998 \\
\hline \multirow[t]{2}{*}{ Annual capital } & $19 \%$ of capital cost & 310,946 & Benemann et al., 1998 \\
\hline & 34 & & \\
\hline $\begin{array}{l}\text {, Y.-M., Lee, M.-K. } \\
\text { atu. (Auteur de cor } \\
\text { atus, Limitations, ar }\end{array}$ & $\begin{array}{l}\text { Comment citer ce document: } \\
\text {-W., Marone, A., Trably, E., Shin, S.-R., Kim, M.-C } \\
\text { dance) (2018). Biohydrogen production from Food Fon } \\
\text { ire Perspectives. Bioresource Technology (248), } \\
\text { 10.1016/i.biortech.2017.06.107 }\end{array}$ & $\begin{array}{l}\text { Cho, S.-K., } \\
\text { aste: Current } \\
\text { 7., DOI : }\end{array}$ & \\
\hline
\end{tabular}


cost

\begin{tabular}{cccc} 
Others & Labor cost (20\% of total operating cost) & 91,428 & Luccio et al., 2002 \\
\hline Profit & $\begin{array}{l}10 \% \text { of treatment cost } \\
\text { (100 USD/ton waste) }\end{array}$ & 360,000 & \\
Waste treatment & A & 360,000 & NABO, 2012 \\
\hline
\end{tabular}

Production cost Annual cost (Capital cost/20y + operating cost)/Annual $\mathrm{H}_{2}$ production

\section{2 $\mathrm{USD} / \mathrm{kg} \mathrm{H}$}

Table 5 Performance of two-stage fermentation system converting food waste to $\mathrm{H}_{2}$ and $\mathrm{CH}_{4}$

\begin{tabular}{|c|c|c|c|c|c|}
\hline$\gg 1^{\mathrm{st}} \mathrm{st}$ & & $2^{\text {nd }} \mathrm{st}$ & & & \\
\hline $\begin{array}{c}\mathrm{H}_{2} \text { yield per } \\
\text { added } \\
\text { substrate }\end{array}$ & $\begin{array}{c}\text { Bioenergy } \\
\text { recovery } \\
\text { (\% of FW } \\
\text { input) }\end{array}$ & $\begin{array}{l}\mathrm{CH}_{4} \text { yield } \\
\text { (per added } \\
\text { substrate) }\end{array}$ & $\begin{array}{c}\text { Bioenergy } \\
\text { recovery } \\
\text { (\% of FW } \\
\text { input) }\end{array}$ & $\begin{array}{c}\mathrm{COD} \\
\text { removal } \\
(\%)\end{array}$ & Reference \\
\hline $\begin{array}{c}65 \mathrm{~mL} \mathrm{H}_{2} / \mathrm{g} \\
\mathrm{VS}\end{array}$ & 6 & $\begin{array}{c}546 \mathrm{~mL} \mathrm{CH}_{4} / \mathrm{g} \\
\mathrm{VS}\end{array}$ & 82 & N.A. ${ }^{a}$ & $\begin{array}{c}\text { Wang and Zhao, } \\
2009\end{array}$ \\
\hline \multicolumn{6}{|c|}{35} \\
\hline $\begin{array}{l}\text { H. (Auteur de } \\
\text { us, Limitations }\end{array}$ & $\begin{array}{l}\text { Com } \\
\text {, S.-W., M } \\
\text { pondance } \\
\text {-uture Per }\end{array}$ & $\begin{array}{l}\text { ter ce documer } \\
\text { A., Trably, E., S } \\
\text {. Biohydrogen } \\
\text { s. Bioresource }\end{array}$ & $\begin{array}{l}\text { R., Kim, N } \\
\text { ion from F } \\
\text { ology (248 }\end{array}$ & $\begin{array}{l}\text { ho, S.-K., } \\
\text { ste: Curr } \\
\text {, DOl : }\end{array}$ & \\
\hline
\end{tabular}




\begin{tabular}{|c|c|c|c|c|c|}
\hline $\begin{array}{c}310 \mathrm{~mL} \mathrm{H}_{2} / \mathrm{g} \\
\mathrm{VS}\end{array}$ & 28 & $\begin{array}{c}210 \mathrm{~mL} \mathrm{CH}_{4} / \mathrm{g} \\
\mathrm{VS}\end{array}$ & 70 & $\begin{array}{c}73 \% \\
\text { (on a VS } \\
\text { basis) }\end{array}$ & $\begin{array}{c}\text { Han and Shin, } \\
2004\end{array}$ \\
\hline $\begin{array}{c}290 \mathrm{~mL} \mathrm{H}_{2} / \mathrm{g} \\
\mathrm{VS}\end{array}$ & 19 & $\begin{array}{c}240 \mathrm{~mL} \mathrm{CH}_{4} / \mathrm{g} \\
\mathrm{VS}\end{array}$ & 52 & 95 & Han et al., 2005 \\
\hline $\begin{array}{c}205 \mathrm{~mL} \mathrm{H}_{2} / \mathrm{g} \\
\mathrm{VS}\end{array}$ & 11 & $\begin{array}{c}464 \mathrm{~mL} \mathrm{CH}_{4} / \mathrm{g} \\
\mathrm{VS}\end{array}$ & 86 & 93 & Chu et al., 2008 \\
\hline $\begin{array}{c}161 \mathrm{~mL} \mathrm{H}_{2} / \mathrm{g} \\
\mathrm{VS}\end{array}$ & 9 & $\begin{array}{c}250 \mathrm{~mL} \mathrm{CH}_{4} / \mathrm{g} \\
\mathrm{COD}\end{array}$ & 70 & 89 & Jung et al., 2013 \\
\hline $\begin{array}{c}41 \mathrm{~mL} \mathrm{H}_{2} / \mathrm{g} \\
\mathrm{COD}\end{array}$ & 3 & $\begin{array}{c}310 \mathrm{~mL} \mathrm{CH}_{4} / \mathrm{g} \\
\mathrm{COD}\end{array}$ & 68 & 94 & $\begin{array}{l}\text { onopoulou et } \\
\text { al., } 2008\end{array}$ \\
\hline
\end{tabular}

${ }^{\mathrm{a} N}$.A. $=$ Not available 
- Critical reviews on dark fermentation of food waste (FW)

- Current status of dark fermentation with strategies applied for enhancement

- Technical and economical limitation of dark fermentation performance of FW

- Strategies to increase $\mathrm{H}_{2}$ yield and gain more energy

- Integrated system converting fermentation effluent to various fuels and chemicals 